\title{
Nutritional status of third trimester pregnant women correlates positively with birth weight
}

\author{
Ratna Ernawati, Bangun Trapsila Purwaka, Budi Prasetyo \\ Department of Obstetric and Gynecologic, Faculty of Medicine, Universitas Airlangga \\ Dr. Soetomo Hospital, Surabaya
}

\begin{abstract}
ABSTRAK
Tujuan: Mengidentifikasi korelasi antara status gizi (asupan energi, makronutrien dan cairan) pada ibu hamil trimester ketiga dan berat lahir.

Bahan dan Metode: studi kohort prospektif analitik korelatif di Puskesmas Jagir, Surabaya dengan sampel terdiri dari wanita hamil sehat berusia 20-35 tahun pada trimester ketiga dan bayinya $(\mathrm{n}=34)$. Responden mencatat asupan cairan setiap hari selama 7 hari (metode catatan) dan makanan selama 24 jam (metode recall). Kecukupan asupan energi, makronutrien dan cairan (ratarata) dinilai berdasarkan AKG 2012. BLR bila <2500 g. Analisis statistik menggunakan korelasi Pearson dan Spearman rho dengan tingkat signifikansi $\mathrm{p}<0,05$.

Hasil: pada ibu hamil trimester ketiga asupan energi (r: 0,854, p: 0,0001) dan karbohidrat (r: 0,912, p: 0,0001) memiliki korelasi positif yang kuat, asupan protein memiliki korelasi positif sedang (r: 0,519, p: 0,0001), asupan lemak (r: 0,425p: 0,012) dan cairan (r: 0,469 p: 0,005) memiliki korelasi positif dengan berat lahir. Prevalensi BBLR di Puskesmas Jagir Surabaya adalah 14,7\%

Simpulan: Status gizi ibu hamil trimester ketiga berkorelasi positif dengan berat lahir. (MOG 2017;25:41-47)
\end{abstract}

Kata kunci: asupan energi, asupan makronutrien, asupan cairan, berat lahir

\begin{abstract}
Objectives: to identify correlation between nutritional status (energy, macronutrient and fluid intake) of the third trimester pregnant women and birth weight.

Materials and Methods: correlative analytic prospective cohort's study in Public Health Center Jagir, Surabaya with sample comprising healthy pregnant women aged 20-35 years in the third trimester and their newborns $(n=34)$. Respondents noted fluid intake every day for 7 days (record method) and food for 24 hours (recall method). Adequacy of energy intake, macronutrient and fluid (mean) was assessed based on AKG 2012. LBW when $<2500$ g. Statistical analysis used Pearson correlation's and Spearman's rho with test with significance level of $\mathrm{p}<0.05$.

Results: in third trimester pregnant women energy intake (r: 0.854, p: 0.0001) and carbohydrates (r:0.912, p:0.0001) had strong positive correlation, protein intake had moderate positive correlation (r: $0.519, \mathrm{p}: 0.0001)$, fat intake (r: $0.425 \mathrm{p}: 0.012$ ) and fluid (r: $0.469 \mathrm{p}: 0.005$ ) had positive correlation with birth weight. The prevalence of LBW in Public Health Center Jagir Surabaya was $14.7 \%$.

Conclusion: Nutritional status of third trimester pregnant women correlates positively with birth weight. (MOG 2017;25:41-47)
\end{abstract}

Keywords: energy intake, macronutrient intake, fluid intake, birth weight

Correspondence: Ratna Ernawati, Department of Obstetrics and Gynecology, Faculty of Medicine, University of Airlangga, Hospital Dr. Soetomo, Surabaya, East Java, Indonesia, phone: +62315501474, email: ratna_unair94@ yahoo.co.id

\section{INTRODUCTION}

Pregnant women are nutritionally vulnerable group. Malnutrition in pregnant women causes complications for fetal growth, perinatal morbidity and mortality, one of which is Low Birth Weight (LBW). The high rates of poverty and low education levels affect the incidence of malnutrition in pregnant women $(30 \%$ of the population) which resulted in increased rates of LBW in Indonesia $(10.2 \%) .{ }^{1-3}$ Increased energy need until the end of the third trimester of pregnancy is for fetal and placental

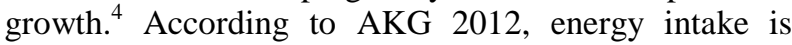
inadequate at age 20-29 year if $<2450 \mathrm{kcal}$, age 30-35 years $<2550 \mathrm{kcal}$ and adequate at age 20-29 years if $>2450 \mathrm{kcal}$, aged $30-35$ years $>2550 \mathrm{kcal} .^{5}$

The main energy source for fetus is glucose. Changes in carbohydrate metabolism during pregnancy is intended to avoid the fluctuations of glucose in the fetus. Transport of glucose to the fetus is through the mechanism of active transport and simple diffusion. ${ }^{6}$ By AKG 2012, less carbohydrate intake occurs at age 20-29 years: <349 grams, age 30-35 years: <363 grams and sufficient at age 20-29 years: >349 grams, age 30-35 years: >363 grams. ${ }^{5}$ Fat metabolism during pregnancy is influenced by maternal hyperlipidemia and insulin resistancy. 7,8 Fetal fat is derived from mothers' fat $(40 \%)$, the rest are synthesized itself, used as the source of carbohydrate energy saver, the growth of the central nervous system and nerve cell wall. The numbers are increasing rapidly in the last month of pregnancy along with the increasing weight of the fetus. ${ }^{8,9}$ AKG 2012 showed that fat intake is inadequate at age 20-29 years if $<76$ grams, age $30-35$ years $<77$ grams and adequate at age 20-29 years if $>76$ grams, age $30-35$ years if $>77$ grams. $^{5}$

Protein is required to form the structure of cells, tissues and constituent enzyme. ${ }^{10}$ In at term pregnancy, fetal and placental weight is about $4 \mathrm{~kg}$ and $500 \mathrm{~g}$, consisting of proteins, transferred through the placenta in the form 
of amino acids that are synthesized by the fetus into tissue protein. ${ }^{8-10}$ According to AKG 2012, the intake of protein is inadequate at age $20-29$ years if $<85$ grams, age 30-35 years if $<70$ grams and adequate at age 20-29 years if $>85$ grams, age 30-35 years if $>70$ grams .

At the second to third trimester, amniotic fluid circulation and regulation is through the mechanism of hydrostatic and osmotic pressure. ${ }^{12}$ Average birth weight is estimated to contain $2400 \mathrm{~g}$ of water. During pregnancy, increased water needs to support the circulation of the fetus, amniotic fluid production, and an increase in blood volume, influenced by maternal activity, ambient temperature, residence, etc. ${ }^{13}$ According to AKG 2012, fluid intake is inadequate eif $\langle 2600 \mathrm{ml}$ and adequate if $>$ $2600 \mathrm{~mL}^{5}$

24-hour food recall and food records are the methods used in determining the nutritional status of individuals or groups by measured the amount and type of nutrients consumed. Food recall (sensitivity 96.2\%, specificity $53.1 \%$ and $77.3 \%$ positive predictor value) is retrospective, easy, cheap, fast, and give a real picture of the subjects' diet. Food record (sensitivity $86.8 \%$, specificity $81.3 \%$ and $88.5 \%$ positive predictor value) is a prospective, not relying on memory and more accurate approach. $^{14}$

Birth weight is the weight of the baby at birth and weighed immediately after birth, normal when $\geq 2500$ 4000 grams, and if <2500 grams (up to 2499 grams) is regarded as low birth weight (LBW). ${ }^{15,16}$ Factors affecting birth body weight is the internal factors (maternal age, birth spacing, parity, hemoglobin levels, nutritional status of pregnant women, and disease during pregnancy) and external factors (environmental, economic and social levels of pregnant women). ${ }^{17}$ Mothers with risk age category $(<20$ years and $>35$ years) have increasing opportunity to give birth to LBW. ${ }^{15,16}$ Mother with parity> 4, gave birth to babies with low birth weight $20.2 \%$. ${ }^{18}$ Interval birth $<2$ years have the opportunity to give birth to LBW 5.11 times. ${ }^{16}$ According Hilli AL (2009), there is a linear relationship between anemia in pregnant mothers with birth weight. ${ }^{19}$ Nutritional status of pregnant women affect the fetal growth. ${ }^{20}$ According to Villar, the odds ratio in pregnant women with malnutrition to have LBW is $0.77 .^{21}$

Mothers who have diseases have a risk of delivering low birth weight 2.91 times. ${ }^{16}$ Hygiene and environmental health affects the health of pregnant women as vulnerable to diseases. ${ }^{17}$ Living in high altitude disrupt the transport of oxygen, leading to fetal hypoxia. ${ }^{22}$ Maternal employment related to energy expenditure contributes to LBW delivery. Educational level associa- ted with understanding and concern about the hazards that may occur to herself or the baby. ${ }^{23}$

\section{MATERIALS AND METHODS}

This study design was prospective cohort observational analytic, community-based, at Public Health Center Jagir Surabaya, held in March - December 2014. The population in this study were pregnant women who had antenatal care at Public Health Center Jagir during the period March 2014 to May 2014. The sample was 3rd trimester pregnant women and their newborn.

Inclusion criteria for this study were pregnant women 20-35 years old, third trimester (28-42 weeks gestation), singleton pregnancy, declared healthy by anamnesis, physical examination and laboratory, third trimester ultrasound normal, BMI (18.5 to $29.9 \mathrm{~kg} / \mathrm{m} 2)$, residing in Surabaya at least 1 year, at least high school education, and willing to participate in this study.

The exclusion criteria in this study were to have a family history of inherited disorders, history of recurrent miscarriage, birth history with congenital abnormalities, smoking mother, alcoholic mother, parity is more than 4 , spacing pregnancies less than 2 years. Drop out criteria were the respondent cannot finish the daily record of fluid intake during the 7-day and 24-hour food intake, intrauterine fetal death, preterm labor, fetal congenital abnormalities, maternal pre-eclampsia /eclampsia.

The sample in this study were 37 pregnant women who had antenatal care at Public Health Center Jagir from March to May 2014, revealed 3 respondents drop out, as they since resettled outside Surabaya, so they could not finish the food and fluid intake recording. Thus, the samples that met the criteria in this study amounted to 34 patients $(n=34)$. After screening and physical examination, and are willing to participate in this study are given a questionnaire to fill fluid intake diary for 7 consecutive days and food intake in the last 24 hours on day 7 , measured using household size, and conducted surveillance by nutritionists through home visits every day.

The instruments used in this research was the weight scale Tanita BC 571, upper arm circumference measuring tape SECA, height measuring instruments SECA, complete blood screening tools, baby weight scales, questionnaires, diaries of fluid intake for 7 days and recall of food intake for 24 hours.

Data of energy intake (kcal), macronutrients (g) and fluid $(\mathrm{mL})$ obtained will be analyzed with Nutrient 
Analysis Software Survey 2007 to the data mean. Statistical analysis using Pearson Correlation and Spearman's rho with significance level of $\mathrm{p}<0.05$ using SPSS software.

\section{RESULTS}

Of the 34 respondents in this study, the average age of mothers was 27.44 years, with an average BMI was $26.114 \mathrm{~kg} / \mathrm{m} 2$ and an average birth spacing was 2.65 years.

Table 1. Characteristics of respondents by age (years), birth spacing (years) and maternal BMI $\left(\mathrm{kg} / \mathrm{m}^{2}\right)$ at third trimester

\begin{tabular}{lllllll}
\hline & $\mathrm{N}$ & Mean & SD. & Med. & Min. & Max. \\
\hline Age & 34 & 27.44 & 3.933 & 28.00 & 21.00 & 34.00 \\
$\begin{array}{l}\text { Birth } \\
\text { spacing }\end{array}$ & 34 & 2.647 & 2.159 & 3.000 & 3.00 & 6.00 \\
BMI & 34 & 26.114 & 2.431 & 25.865 & 22.04 & 29.87 \\
\hline
\end{tabular}

Respondents' characteristics by education obtained the majority is high school education, about $67.6 \%$, followed by $20.6 \%$ diplomas and bachelor's degree about $11.8 \%$, as listed in Table 2.

Table 2. The frequency distribution of respondents by education

\begin{tabular}{lllll}
\hline Education & Frequency & Percent & $\begin{array}{l}\text { Valid } \\
\text { percent }\end{array}$ & $\begin{array}{l}\text { Cumulative } \\
\text { percent }\end{array}$ \\
\hline High school & 23 & 67.6 & 67.6 & 67.6 \\
Diploma & 7 & 20.6 & 20.6 & 88.2 \\
Bachelor & 4 & 11.8 & 11.8 & 100.0 \\
\hline Total & 34 & 100.0 & 100,0 & \\
\hline
\end{tabular}

Most of the respondents occupation was housewife about $50 \%$, and partly working as an employee, merchants and factory workers (Table 3 ).

Table 3. The frequency distribution of respondents by occupation

\begin{tabular}{lllll}
\hline Occupation & Frequency & Percent & $\begin{array}{l}\text { Valid } \\
\text { percent }\end{array}$ & $\begin{array}{l}\text { Cumulative } \\
\text { percent }\end{array}$ \\
\hline Factory & 2 & 5.9 & 5.9 & 5.9 \\
workers & & & & \\
Merchants & 5 & 14.7 & 14.7 & 20.6 \\
Employee & 10 & 29.4 & 29.4 & 50.0 \\
Housewife & 17 & 50.0 & 50.0 & 100.0 \\
\hline Total & 34 & 100.0 & 100.0 & \\
\hline
\end{tabular}

Maternal parity $52.9 \%$ obtained a second pregnancy, first pregnancy is approximately $35.3 \%, 11.8 \%$, and the remaining third pregnancy (Table 4 ).
Table 4. The frequency distribution of respondents by parity

\begin{tabular}{lllll}
\hline Parity & Frequency & Percent & $\begin{array}{l}\text { Valid } \\
\text { percent }\end{array}$ & $\begin{array}{l}\text { Cumulative } \\
\text { percent }\end{array}$ \\
\hline, 00 & 12 & 35.3 & 35.3 & 35.3 \\
1.00 & 18 & 52.9 & 52.9 & 88.2 \\
2.00 & 4 & 11.8 & 11.8 & 100.0 \\
Total & 34 & 100.0 & 100.0 & \\
\hline
\end{tabular}

The results mean energy intake was $1742.68 \mathrm{kcal}$, the average intake of carbohydrate $259.72 \mathrm{~g}$, mean protein intake $62.47 \mathrm{~g}$, and the average fat intake was $60.56 \mathrm{~g}$. As for the mean intake of fluid obtained was $746.12 \mathrm{ml}$. (Table 5)

Table 5. Characteristics of respondents based on energy (kkal), macronutrient $(\mathrm{g})$ and fluid $(\mathrm{mL})$ intake

\begin{tabular}{llllll}
\hline & Energy & Carbohydrate & Fat & Protein & Fluid \\
\hline $\mathrm{N}$ & 34 & 34 & 34 & 34 & 34 \\
Mean & 1742.68 & 259.72 & 60.56 & 62.47 & 746.12 \\
$\mathrm{SD}$ & 551.63 & 84.16 & 26.47 & 26.82 & 401.29 \\
Med & 1727.00 & 237.3500 & 56.3500 & 54.2000 & 659.50 \\
Min. & 782.00 & 114.90 & 17.30 & 17.10 & 302.00 \\
Max. & 2933.00 & 429.60 & 146.80 & 144.10 & 2276.00 \\
\hline
\end{tabular}

Adequacy of energy intake, macronutrient and fluid 3rd trimester pregnant women in this study, the results largely below the standard reasonably based AKG 2012. sufficient energy intake of about $8.8 \%$, carbohydrates $17.7 \%$, fat $23.5 \%$, protein $20.6 \%$ and $2.9 \%$ fluid. The rest of the intake is less (Table 6).

Table 6. Adequacy of energy, macronutrient and fluid intake by $\mathrm{AKG}$ in 2012

\begin{tabular}{llllll}
\hline & $\begin{array}{l}\text { Energy } \\
\mathrm{n}(\%)\end{array}$ & $\begin{array}{l}\text { Carbohid } \\
\mathrm{n}(\%)\end{array}$ & $\begin{array}{l}\text { Fat } \\
\mathrm{n}(\%)\end{array}$ & $\begin{array}{l}\text { Protein } \\
\mathrm{n}(\%)\end{array}$ & $\begin{array}{l}\text { Fluid } \\
\mathrm{n}(\%)\end{array}$ \\
\hline Ade. & $3(8.8)$ & $6(17.7)$ & $8(23.5)$ & $7(20.6)$ & $1(2.9)$ \\
Inade. & $31(91.2)$ & $28(82.4)$ & $26(76.5)$ & $27(79.4)$ & $33(97.1)$ \\
\hline
\end{tabular}

As for birth weight showed LBW infants by 5 (14.7\%) and the rest of normal birth weight of about $85.3 \%$ (Table 7)

Table 7. Frequency distribution of birth weight

\begin{tabular}{lclll}
\hline $\begin{array}{l}\text { Birth } \\
\text { weight }\end{array}$ & Frequency & Percent & $\begin{array}{l}\text { Valid } \\
\text { percent }\end{array}$ & $\begin{array}{l}\text { Cumulative } \\
\text { percent }\end{array}$ \\
\hline$<2500 \mathrm{~g}$ & 5 & 14.7 & 14.7 & 14.7 \\
$\geq 2500 \mathrm{~g}$ & 29 & 85.3 & 85.3 & 100.0 \\
Total & 34 & 100.0 & 100.0 & \\
\hline
\end{tabular}

The results of the analysis of the data normality test by Kolmogorov-Smirnov obtained energy and macronutrient intake obtain results $\mathrm{p}$ value $>0.05$ means the 
normal distribution data that is used by the Pearson correlation test, whereas for fluid intake data is not normally distributed, with a value of $\mathrm{p}<0.05$ so that the test used by Spearman's rho test. The relationship between energy intake in third trimester pregnant women with birth weight, by Pearson correlation analysis, have a correlation coefficient of 0.854 (p-value 0.0001 ), which means the power of correlation are strong $(\mathrm{r} .0,7-1)$ and positive correlation ( $\mathrm{r}$ tend to number +1$)$. The relationship between macronutrient intake consisting of carbohydrate, fat and protein intake in third trimester pregnant women with birth weight, have a correlation coefficient respectively of 0.912 (pvalue 0.0001 ); 0.425 (p-value 0.012 ) and 0.519 (p-value 0.002 ). This means that the relationship between energy and carbohydrate intake with birth weight have a strong positive correlation. As for the protein intake have a moderate positive correlation (strength of the correlation between 0.5-0.7) with birth weight and fat intake has a weak positive correlation $(r<0.5)$. The result of this correlation can be seen in Table 9 .

Table 9. Correlation between energy and macronutrient intake with birth weight (Pearson Correlation)

\begin{tabular}{llllll}
\hline & BW & En. & CBH & Fat & Prot. \\
\hline BW pearson & 1 & .854 & .912 & .426 & .519 \\
Sig.(2-tail) & & .0001 & .0001 & .012 & .002 \\
N & 34 & 34 & 34 & 34 & 34 \\
En. pearson. & .854 & 1 & .866 & .725 & .771 \\
Sig.(2-tail) & .0001 & & .0001 & .0001 & .0001 \\
N & 34 & 34 & 34 & 34 & 34 \\
CBH pearson &, 912 &, 866 & 1 & .360 & .476 \\
Sig.(2-tail) & .0001 & .0001 & & .036 & .004 \\
N & 34 & 34 & 34 & 34 & 34 \\
Fat pearson cor. & .426 & .725 & .360 & 1 & .625 \\
Sig.(2-tail) & .012 & .0001 & .036 & & .0001 \\
N & 34 & 34 & 34 & 34 & 34 \\
Prot. Pearson & .519 & .771 & .476 & .625 & 1 \\
Sig.(2-tail) & .002 & .0001 & .004 & .000 & \\
N & 34 & 34 & 34 & 34 & 34 \\
\hline Energy intake = En. & \multicolumn{5}{c}{ Carbohydrate intake = CBH } \\
Protein intake = Prot. & \multicolumn{5}{c}{ Birth weight = BW } \\
\end{tabular}

Correlation between fluid intake in third trimester pregnant women with birth weight, through Spearman's rho test found a weak positive correlation with a correlation coefficient of 0.469 and the value of significance (p-value) of 0.005 (Table 10).

Table 10. Correlation between fluid intake with birth weight (Spearman's rho)

\begin{tabular}{llll}
\hline & & & Fluid \\
\hline Spearman's rho & Birth & Correlation & .469 \\
& weight & coefficient & \\
& & Sig.(2-tailed) & .005 \\
& & $\mathrm{~N}$ & 34 \\
\hline
\end{tabular}

\section{DISCUSSION}

In this study, groups age range was from 20 to 35 years because this age group belonged to lower the risk of LBW, with an average of 27.4 years. In pregnancy at age under 20 years, the development of reproductive organs and physiological function is not optimal, as well as insufficient nutritional requirements for growth and development itself and also to the fetus and placenta. Pregnancy over age 35 is not recommended, since in this age diseases, such as hypertension, which will lead to preeclampsia and eclampsia, often appears. ${ }^{15,16}$

Respondents living in the city of Surabaya for at least 1 year, so that environmental factors (hygiene and environmental health, also altitude) can be said to be homogeneous. Most respondents were housewives (50\%), where daily activities are mostly domestic activities in the house. Highest level of education of respondents are high school $(67.6 \%)$, highly educated woman tends to pay more attention to the health of themselves and their families, while women with low education levels, due to their lack of understanding of the dangers that can befall a pregnant mother and her baby. ${ }^{23}$

Birth spacing gained an average of 2,647 years. According to Sistiarini 2008, short birth spacing $(<2$ years) will cause a mother is not enough to recover his body after giving birth before, so the chance to give birth to LBW 5.11 times compared with mothers with birth spacing $>2$ years. ${ }^{15,16}$ In this study, a primigravida as much as $35.3 \%$ and $64.7 \%$ as multigravida (parity less than 4). Mother with parity $>4$, tend to gave birth with low birth weight $20.2 \%$, due to reduced vascularization or atrophic changes in the decidua in the past labor so that blood flow to the placenta is not enough. It will be able to interfere with the function that will have an impact on fetal growth. ${ }^{18}$

Of the 34 newborns found 5 cases of low birth weight (14.7\%) with the remaining $85.3 \%$ is normal birth weight. The incidence of LBW in this study is higher than the number of LBW in Indonesia, which was recorded at $10.2 \%$ in $2013 .{ }^{2,3}$

\section{Correlation between energy intake in the third trimester pregnant women and birth weight}

Average energy intake in third trimester pregnant women in this study was $1742.68 \mathrm{kcal} / \mathrm{day}$, under adequacy energy intake based on AKG 2012. Similar findings appear in the other study of northern Pakistan, where energy consumption pregnant women are found in the lower national RDA. ${ }^{24}$ Evidence based of systematic reviews of RCT (Randomized Controlled Trials) about effectiveness of nutrition interventions 
reducing IUGR, showed beneficial effects of supplementation the macronutrient (protein/energy), with overall odds ratio $0.77(95 \%$ CI0.58, $1: 01) .{ }^{21}$ A research-based community in the rural area in Gambia showed that supplementation of pregnant women with snack such as high energy peanut, significantly increased the birth weight $(136 \mathrm{~g}, \mathrm{p}<0.001){ }^{25}$ Although the data obtained from a study in rural India about the effects of malnutrition in pregnant women (797 mothers) to birth weight found no relationship between energy and protein intake in the pregnant women and birth weight. ${ }^{26}$ In this study we found a strong correlation between energy intake in third trimester pregnant women with birth weight, with a correlation coefficient of 0.854 (p-value <0.05) based on the Pearson Correlation test. Another factor that affects birth weight is daily physical activity which is an important variable during the antenatal period, because women have varied physical activity that is working outside home and household domestic work, especially in the state of pregnancy with less than optimal energy intake. In this study in Public Health Center Jagir, most respondents were housewives who had daily activity of domestic activities which was largely carried out in house. ${ }^{27}$

\section{Correlation between macronutrient intake in the third trimester pregnant women and birth weight}

Macronutrient intake in this study, namely carbohydrates, fats and proteins, had a positive correlation to birth weight with different correlation strength. Carbohydrate intake has a strong positive correlation to birth weight (correlation coefficient of 0.912, p-value $<0.05$ by Pearson Correlation test). Carbohydrates are the main energy source for the fetus with the end result of metabolism in the form of glucose that are transferred to the fetus through active transport, which is greater than the simple diffusion process so that levels in fetal blood is almost like the maternal blood levels. Speed glucose utilization in the fetus was $6 \mathrm{mg} / \mathrm{kg} / \mathrm{min}$ in aterm pregnancy. $^{6}$ In normal pregnancy, maternal plasma glucose levels become significantly lower, partly because of the uptake of glucose is by increasing placental blood flow. Changes in carbohydrate metabolism is to support the supply of food for the fetus as well as preparation for lactation. ${ }^{6,7}$ So carbohydrate has the strongest correlation to birth weight because carbohydrates is the largest contributor to energy intake, carbohydrates are also the only macronutrient compo-nents that can be transferred to the fetus through the mechanism of active transport and simple diffusion.

As for the protein intake in this study had a moderate positive correlation with birth weight, weaker than carbohydrates. Products of conception, the uterus and maternal blood, relatively rich in protein than carbohydrates and fat. ${ }^{10}$ According to Hytten and Leitch (1971), the full-term pregnancy, fetal and placental weight is about $4 \mathrm{~kg}$ and $500 \mathrm{~g}$ of weight which is protein. ${ }^{8}$ The concentration of amino acids in the fetal compartment is higher than the maternal compartment. ${ }^{11}$ Protein across the placenta is especially in the form of amino acids which are then synthesized by the fetus into tissue protein. At the end of pregnancy, an estimated protein requirement is about $1.8 \mathrm{~g} / \mathrm{kg} / \mathrm{hr} .^{9}$ Protein is needed to form new tissues, as well as the placenta and fetus. Protein is also needed to support the growth and differentiation cell. ${ }^{8}$

Fat intake has a weak positive correlation with birth weight. During pregnancy maternal hyperlipidemia occurs. In normal pregnancy, levels of fat in the blood flow will increase at the end of third trimester. ${ }^{3.7}$ Because fetus depends mainly on the transfer of fatty acids across the placenta, it would require considerable fat intake in pregnant women. Transport of fatty acids across the placenta about $40 \%$ of the mother's fat, the rest is synthesized by the fetus. Both fat and protein increased rapidly in the last month of pregnancy along with the increasing weight of the fetus. Changes in body fat content follow the pattern of water and protein content. Until the 30th week of pregnancy it is estimated that most of the fat is at various locations of cell membranes. After week 30 of pregnancy, the fat stored in adipose tissue and increasing rapidly. Because the protein and fat cannot be directly transferred to the fetus through an active transport mechanism such as glucose in the metabolism of carbohydrates, fat is added to use for the growth of the central nervous system and nerve cell wall. Additionally, an increase in insulin resistance in late pregnancy suppress lipolysis, so that excessive intake of fat will be stored in maternal adipose reserves. ${ }^{7-9}$ Thus it is plausible that the intake of carbohydrates as the largest energy producer (compared to fats and proteins) has a stronger correlation to birth weight, as it is found in this study.

\section{Correlation between macronutrient intake and energy intake}

Largest energy intake contributed by carbohydrate intake with a correlation coefficient of 0.866 (p-value $<0.01$ ) with Pearson Correlation test, followed by protein and fat. In accordance with the theory of macronutrient metabolism in the human body that carbohydrates are converted into glucose which is a simple form water soluble and easily transported to all the cells in order to supply energy. ${ }^{7}$ While the protein is relatively richer component of conception product, the uterus and maternal blood than carbohydrates and fats, it will be used mostly to form the structure of cells and 
tissues as well as the constituent enzymes compared to energy production. ${ }^{10}$ Fat is one of the energy source and as a solvent of fat soluble vitamins. Fat needs depend on the energy requirements for weight gain during pregnancy. ${ }^{7}$ During pregnancy maternal hyperlipidemia occurs. Since power consumption increases at the end of pregnancy, the pregnant woman's body will adjust to the way of saving the use of carbohydrates as an main energy source, and increasing the use of energy from other sources, the fat. Insulin strongly suppresses the occurrence of lipolysis, resulting insulin resistance that will increase the release of free fatty acids in the circulation and lipid oxidation. ${ }^{8}$

\section{Correlation between fluid intake in third trimester pregnant women and birth weight}

At 2nd-3rd trimester of pregnancy, an important component of the circulatory system and the regulation of amniotic fluid volume is the flow of fluid from the amniotic fluid to the circulation of the fetus through the mechanism of hydrostatic and osmotic pressure. During pregnancy, the need for fluid will increase because it is used to support the fetal circulation, production of amniotic fluid, and blood volume. ${ }^{12}$ Fluid requirement is influenced by many factors such as maternal activity, ambient temperature, residence etc. ${ }^{13}$ In this study the mean of fluid intakes in the third trimester pregnant women in Public Health Center Jagir was $746.12 \mathrm{~mL}$, very far below AKG 2012. Spearman's rho test revealed a weak positive correlation between fluid intake with birth weight, with a correlation coefficient of 0.469 and the value of significance ( $p$-value) of 0.005 . The total change of water and protein levels in fetal growth turned parallel to the birth weight. Average birth weight is estimated to contain $2400 \mathrm{~g}$ of water and $400 \mathrm{~g}$ of protein. Generally during pregnancy decreased the proportion of water and reverse the increase in protein, fat and minerals. ${ }^{13}$

Lack of fluid intake in the third trimester pregnant women who did the ANC in Public Health Center Jagir in this study period may be caused by several factors, such as ignorance of the pregnant women about the importance of fluid intake in pregnancy, so there is a need of more studies on the knowledge of fluid adequate level in pregnant women. The knowledge of a mother will affect decision-making and also will have an effect on behavior. Mother with knowledge of good nutrition is likely to provide adequate nutrition for the baby. Moreover, when a mother is entering a period of cravings, she will not want to eat, having nausea and unpalatable taste. Although in such circumstances, if someone has a good knowledge, then she will attempt to meet the nutritional needs and also for her baby. ${ }^{28}$

\section{Correlation between nutritional status of third trimester pregnant women and newborn's weight}

In this study, the correlation between energy intake, macronutrient and fluid of 3rd trimester pregnant women and newborns weight with various levels of correlation strength, all had correlation coefficient $>0$ and close to 1 . This indicated positive correlation between energy intake, macronutrient and fluid in third trimester pregnant women and newborn's weight, so if intake increases, the birth weight will also increase. Healthy nutrition is one of the factors that affect the reproductive process to function normally. Maternal nutritional status shown to be associated with morbidity and mortality as well as the quality of the next generation. Low birth weight (LBW) is a result of poor maternal nutrition. ${ }^{1-3}$ A community-based study in rural Gambia showed that supplementation of pregnant women with peanut snacks high energy, significantly increasing birth weight $(136 \mathrm{~g}, \mathrm{p}<0.001)$. Food supplementation reduced the prevalence of low birth weight (LBW) from $17.0 \%$ to $11.1 \% .^{25}$

\section{CONCLUSION}

Nutritional status of the third trimester pregnant women correlates positively with newborns weight in Public Health Center Jagir Surabaya with a $14.7 \%$ incidence of low birth weight. This indicates that increasing the nutritional status of third trimester pregnant women may also increase the birth weight of the newborns.

\section{REFERENCES}

1. WHO. Global strategy for infant and young child feeding. Geneva: 2003. p. 12.

2. Badan Pusat Statistik. Statistik Indonesia 2012. Jakarta: Susenas; 2013.

3. Badan Penelitian dan Pengembangan Kesehatan Kementerian Kesehatan RI. Riset Kesehatan Dasar (Riskesdas). 2013.

4. The Food and Nutrition Board. Commission on Life Sciences. Washington, DC: National Academy Press; 1989.

5. Widyakarya Pangan dan Gizi X. Penyempurnaan kecukupan gizi untuk orang Indonesia. 20-21 November 2012. Jakarta.

6. Butte, NF. Carbohydrate and lipid metabolism in pregnancy: normal compared with gestational diabetes mellitus. Am J Clin Nutr. 2000;71(5 Suppl):1256S-61S. 
7. Mel L and Barclay MD. Physiology of Pregnancy. University of Michigan School of Medicine, Ann Arbor, Michigan. 2001.

8. Cunningham, et al. Obesity. William Obstetrics. $23^{\text {rd }}$ edn. 2010: p. 946-57

9. Soetjiningsih. Tumbuh kembang anak. Jakarta: EGC; 1995.

10. Department of Health and Ageing. Healthy Eating at Various Life Stages Pregnant Women. 2009.

11. Cetin I, Nobile de Santis MS, et al. Maternal and fetal amino acid concentrations in normal pregnancies and in pregnancies with gestational diabetes mellitus. Am J Obstet Gynecol. 2005; 192:610.

12. Garite TJ, Weeks J, Peters-Phair K, Pattillo C, Brewster WR. A Randomized controlled trial of the effect of increased intravenous on the course of labor in nulliparous women. Am J Obstet Gynaecol. 2000; $183 ; 1544-8$

13. Montgomery KS. Nutrition column an update on water needs during pregnancy and beyond. J Perinat Educ. 2002;11:40-2.

14. Supariasa IDN, Bakri B, Fajar I. Metode penilaian status gizi. 7th Eds. Jakarta: EGC; 2002.

15. Wiknjosastro. Ilmu Kebidanan. Jakarta:EGC; 2005.

16. Sistiarini. Faktor maternal dan kualitas pelayanan antenatal yang berisiko terhadap kejadian BBLR. Semarang: Universitas Diponegoro; 2008.

17. Bobak. Buku ajar keperawatan maternitas. 4th Edn. Jakarta: EGC; 2005.

18. Simanjuntak. Hubungan anemia pada ibu hamil dengan kejadian BBLR di BPRSU Rantauprat Kab. Labuhan Ratu Tahun 2008. Medan: USU Respository; 2009

19. Hilli AL. The effect of maternal anaemia on cor blood haemoglobin \& newborn birth weight. Kabala Journal of Medical. 2009:2
20. Margerison Zilco CE, Rehkopf D, Abrams B. Association of maternal gestasional weight gain with short- and long-term maternal and child health outcomes. Am J Obstet Gynecol. 2010.

21. Villar J, Gulmezoglu M. Nutritional interventions to prevent intrauterine growth retardation: evidence fromrandomized controlled trials. Eur J Clin Nutr. 1998;52(Suppl 1): S83-S93

22. Huliah. Gambaran ultrastruktur endotil tali pusat dan kapiler terminal, villi plasenta pada kehamilan dengan pertumbuhan janin terhambat dan preeklamsi berat. Thesis. Jakarta: Fakultas Kedokteran Universitas Indonesia; 2006.

23. Fibriani. Faktor-faktor risiko yang mempengaruhi kematian maternal. Thesis. Semarang: Universitas Diponegoro; 2007.

24. Abrams B and Selvin S. Maternal weight gain pattern and birthweight. Obstet Gynecol. 1995;86: 163-9.

25. Ceesay SM, Prentice AM, Cole TJ, et al. Effect on birth weight and perinatal mortalitydietary supplements in rural Gambia: 5 year randomized controlled trial. BMJ. 1997;315: 786-90.

26. Rao S, Yajnik CS, Kanade A, et al. Intake of micronutrient-rich foods in rural Indian mothers is associated with the size of their babies at birth: Pune maternal nutrition study. J Nutr. 2001;31: 1217-24.

27. Tafari N, Naeye RL, Gobezie A. Effects of maternal undernutrition and heavy physical work during pregnancy on birthweight. $\mathrm{Br} \mathrm{J}$ Obstet Gynaecol. 1980;87:222-6

28. Proverawati and Kusumawati. Buku ajar gizi untuk kebidanan. Yogyakarta; Nuha Medika. 2009. 